\title{
PENGARUH PENAMBAHAN ASAM ASKORBAT TERHADAP SIFAT FUNGSIONAL PATI UBI JALAR UNGU (Ipomea batatas L.)
}

\section{(The Effect of Ascorbic Acid Addition on Functional Characteristic of Purple Sweet Potato (Ipomea batatas L.) Starch)}

\author{
Amran Laga $^{1 *}$, Tuflika Primi Putri ${ }^{1)}$, Adiansyah Syarifuddin ${ }^{1}$ ), Nuril Hidayah ${ }^{1)}$ dan \\ Muhpidah ${ }^{1)}$ \\ ${ }^{1)}$ Program Studi Ilmu dan Teknologi Pangan, Fakultas Pertanian, Universitas Hasanuddin, Makassar, Indonesia
}

*) Email Penulis Korespondensi: amranlaga@gmail.com

\begin{abstract}
ABSTRAK
Pati ubi jalar ungu dikenal dengan kandungan antosianin serta memiliki kandungan karbohidrat terutama pati yang tinggi. Ekstraksi pati pada ubi jalar ungu dapat menyebabkan terjadinya browning karena adanya enzim PPO yang mengakibatkan menurunnya kandungan antosianin dalam pati yang dihasilkan. Asam askorbat dapat digunakan sebagai salah satu agen anti browning. Rancangan penelitian menggunakan RAL (Rancangan Acak Lengkap) Faktorial dengan perlakuan variasi penambahan asam askorbat dan variasi lama pengeringan. Hasil analisa yang diperoleh yaitu pengeringan pati ubi jalar ungu dapat dilakukan selama 4 jam karena pada lama waktu tersebut kadar air telah konstan untuk lama pengeringan selanjutnya. Kandungan antosianin pati ubi jalar ungu menurun dengan bertambahnya konsentrasi penambahan asam askorbat, namun penambahan asam askorbat menyebabkan peningkatan antioksidan pati ubi jalar ungu karena asam askorbat merupakan salah satu jenis antioksidan.
\end{abstract}

Kata Kunci: antioksidan,antosianin,pati ubi jalar ungu

\section{ABSTRACT}

Purple sweet potato starch is known for its anthocyanin content and has a high carbohydrate content, especially starch. Starch extraction in purple sweet potato can cause browning due to the presence of PPO enzymes which results in decreased anthocyanin content in the resulting starch. Ascorbic acid can be used as an anti-browning agent. The analysis results obtained are the drying of purple sweet potato starch can be done for 4 hours because at that time the water content has been constant for a long time of further drying. The anthocyanin content of purple sweet potato starch decreases with increasing concentration of the addition of ascorbic acid, but the addition of ascorbic acid causes an increase in antioxidants of purple sweet potato starch because ascorbic acid is one type of antioxidant.

Keywords: antioksidan, antosianin, purple sweet potato starch

\section{PENDAHULUAN}

Ubi jalar merupakan sumber karbohidrat terbanyak keempat setelah padi, jagung, dan ubi kayu. Menurut Badan Pusat Statistik bahwa pada tahun 2015 produksi ubi jalar di Indonesia mencapai 2,2 juta ton dengan luas lahan sekitar 143 ribu ha. Ubi jalar dikenal dalam tiga kelompok yaitu ubi jalar putih, ubi jalar kuning, dan ubi jalar ungu. Ubi jalar ungu mempunyai kandungan nutrisi yang lebih 
tinggi dibandingkan dengan ubi jalar putih dan ubi jalar kuning. Selain itu, terdapat kandungan pigmen antosianin pada ubi jalar ungu yang dapat berperan sebagai antioksidan (Widhaswari \& Putri, 2014).

Antosianin merupakan salah satu pigmen alami yang dapat memberikan warna merah atau ungu pada bunga, batang, daun, dan umbi (Afandy, Nuryanti, \& Diah, 2017; Helmalia, Putrid, \& Dirpan, 2019) Menurut (Kristijarti \& Arlene, 2012), kandungan antosianin pada ubi jalar ungu berkisar antara 14,68- $210 \mathrm{mg} / 100 \mathrm{~g}$ bahan baku. Antosianin memiliki peranan yaitu sebagai antioksidan yang mencegah terjadinya penuaan dan penyakit degenarative, anti mutagenik dan anti karsinogenik, mencegah gangguan fungsi hati, dan anti hipertensi (Arifuddin, 2018; Suda et al., 2003).

Ubi jalar ungu tidak hanya kaya akan kandungan antosianin tetapi juga memiliki kandungan karbohidrat yang tinggi terutama pati (Zhang et al., 2018). Ubi jalar merupakan salah satu komoditas pertanian yang memiliki kekurangan dalam hal daya simpan yang cenderung tidak tahan lama (Ramadani \& Yahya, 2018). Selain itu, pengolahan ubi jalar ungu di masyarakat masih sangat terbatas untuk dikonsumsi hanya sekedar dikukus, digoreng, atau diolah menjadi kripik (Firgianti \& Sunyoto, 2018). Tetapi, dalam pengembangannya ubi jalar dapat dibuat produk antara seperti tepung, pati, dan sawut kering (Suprapto, 2004) Sehingga dilakukan suatu pengolahan ubi jalar ungu untuk memperpanjang daya simpannya dan dapat menghasilkan suatu pangan fungsional. Salah satu cara yang dapat dilakukan adalah dengan ekstraksi pati ubi jalar ungu dengan meminimalkan kehilangan senyawa antioksidannya.

Pencegahan atau penghambatan browning menurut (Marshall, Kim, \& Wei, 2005), dapat dilakukan baik secara fisik maupun secara kimia. Pemanasan, pendinginan, pembekuan, dehidrasi, iradiasi, pemberian tekanan yang tinggi, ultrafiltrasi, dsb merupakan perlakuan fisik untuk pencegahan browning pada bahan pangan. Sedangkan perlakuan kimia dapat dilakukan dengan senyawa pereduksi (antioksidan), pengkelat, asidulan, penghambat enzim, dan agen pengkompleks.

Pencoklatan atau browning yang terjadi pada pati juga dapat dicegah dengan penggunaan berbagai senyawa kimia. Salah satu senyawa yang paling banyak digunakan adalah asam askorbat, karena sangat efektif dalam mengurangi browning, umumnyadikenal aman dan ramah konsumen. Asam askorbat dapat mengurangi o-kuinon, hasil dari oksidasi polifenol yang dikatalisis oleh PPO, kembali menjadi dihidroksi polifenol dan telah banyak digunakan sebagai agen anti kerut untuk pemrosesan buah dan sayuran (Javdani, Ghasemnezhad, \& Zare, 2013; Özoğlu \& Bayındırlı, 2002). Menurut Peraturan Kepala Badan Pengawas Obat dan Makanan Republik Indonesia No.38 Tahun 2013 bahwa asam askorbat aman untuk dikonsumsi secukupnya dalam sehari tanpa batasan tertentu hingga menghasilkan efek yang diinginkan. Potensi asam askorbat sebagai anti browning bergantung pada konsentrasi yang digunakan (Abbasi, Akhtar, Hussain, \& Ali, 2013; . Oleh karena itu, diperlukan suatu perlakuan pendahuluan dalam ekstraksi pati ubi jalar ungu berupa penambahan asam askorbat untuk menghasilkan pati dengan kualitas fisik, kimia, dan fungsional yang baik.

\section{METODOLOGI PENELITIAN}

\subsection{Alat dan Bahan}

Peralatan yang digunakan seperti pada umumnya dalam pembuatan pati yaitu wadah, pisau, kainsaring, saringan, talenan, parut kelapa, blower, grinder, dan ayakan. Sedangkan bahan yang digunakan 
dalam pembuatan pati ubi jalar ungu yaitu ubi jalar ungu, asam askorbat, dan air.

\subsection{Pembuatan Pati Ubi Jalar Ungu}

Ubi jalar ungu dibersihkan dan dikupas, kemudian direndam dalam air. Ubi jalar ungu dikecilkan ukurannya agar diperoleh ukuran yang merata dengan cara diparut dan ditambahkan air dengan perbandingan 3:1, disaring dan dipisahkan antara ampas dan filtrat. Filtrat yang diperoleh diendapkan semalam hingga diperoleh endapan. Setelah itu, endapan dipisahkan dari airnya, kemudian ditimbang untuk ditambahkan dengan asam askorbat dengan variasi konsentrasi $0,5 \% ; 1 \%$; dan $1,5 \%$. Pati yang telah ditambahkan larutan asam askorbat kemudian dikeringkan dengan menggunakan oven blower dengan lama pengeringan 16 jam dengan pengamatan setiap 4 jam.

\subsection{Analisa Pati Ubi Jalar Ungu}

Proses analisa pati ubi jalar ungu meliputi pengujian kadar air, kandungan antosianin, dan aktivitas antioksidan dari masing-masing unit perlakuan. Analisa pati ubi jalar ungu dilakukan di Laboratorium Kimia Analisa dan Pengawasan Mutu Pangan, Universitas Hasanuddin.

\section{HASIL DAN PEMBAHASAN}

Pati ubi jalar ungu yang dihasilkan dengan penggunaan konsentrasi asam askorbat yang berbeda dan variasi lama pengeringan dianalisa dengan parameter kadar air, kandungan antosianin, dan aktivitas antioksidannya.

\subsection{Kadar Air}

Kadar air merupakan kandungan air yang terdapat dalam suatu bahan pangan. Kadar air dalam bahan pangan yang dikeringkan dipengaruhi oleh penggunaan suhu dan lama pengeringan yang dilakukan. Hasil pengujian penambahan asam askorbat terhadap kadar air pati ubi jalar ungu berkisar antara 15,80-18,09\%. Kadar air pati ubi jalar ungu tanpa penambahan asam askorbatsebesar 18,09\% dan cenderung menurun pada pati ubi jalar ungu penambahan asam askorbat 1,5\% diperoleh kadar air sebesar 15,80\%. Semakin meningkat konsentrasi asam askorbat yang ditambahkan maka kadar air pati ubi jalar ungu juga semakin rendah.

Hasil analisis menunjukkan bahwa penambahan asam askorbat dan lama pengeringan terhadap kadar air pati ubi jalar menunjukkan kadar air pati cenderung menurun dengan bertambahnya konsentrasi asam askorbat. Adanya senyawa pengikat, penambahan asam dan bahan pemanis mempengaruhi kandungan air dalam bahan tersebut. Penurunan kadar air karena penambahan asam dipaparkan dalam penelitian (Arifiansyah, 2015) bahwa semakin turunnya kadar air, diduga karena semakin besar konsentrasi asam yang digunakan maka $\mathrm{pH}$ akan turun. Asam askorbat yang ditambahkan selama proses ekstraksi pati menyebabkan keadaan pati atau bahan menjadi asam. Keadaan asam ini menyebabkan pembentukan senyawa-senyawa dalam pati yang menyerap air, sehingga keadaan yang semakin asam akan menyebabkan pembetukan senyawa-senyawa pengikat yang semakin banyak dan menyebabkan kehilangan air akibat pengikatan semakin tinggi.

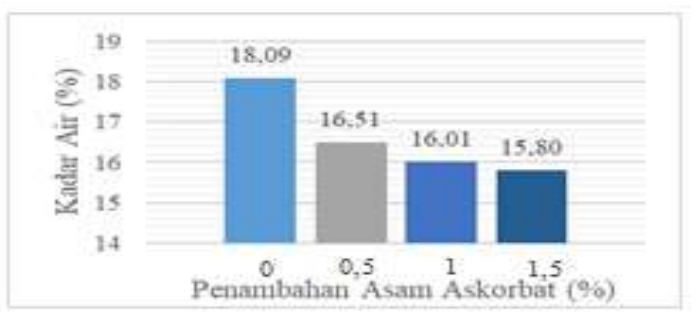

Gambar 1. Hubungan Penambahan Asam Askorbat terhadap Kadar Air Pati UbiJalar Ungu 
Hasil pengujian lama pengeringan terhadap kadar air ubi jalar berkisar antara $8,28-48,51 \%$. Kadar air pati ubi jalar ungu dengan lama pengeringan 0 jam sebesar $48,51 \%$. Kadar air pati ubi jalar ungu pada lama pengeringan 4 hingga 16 jam cenderung konstan yang berkisar antara $8,28-8,90 \%$.

Hasil analisa kadar air pada pati dengam lama pengeringan 4 jam, 8 jam, 12 jam, dan 16 jam cenderung konstan walaupun rata-rata yang diperoleh cenderung fluktuatif. Hal ini diduga karena penambahan asam askorbat yang dilarutkan dalam aquades dengan volume yang tidak terlalu seragam. Namun, kadar air yang dihasilkan telah memenuhi syarat pati SII (Standar Industri Indonesia) yaitu nilai maksimum kadar air $14 \%$.

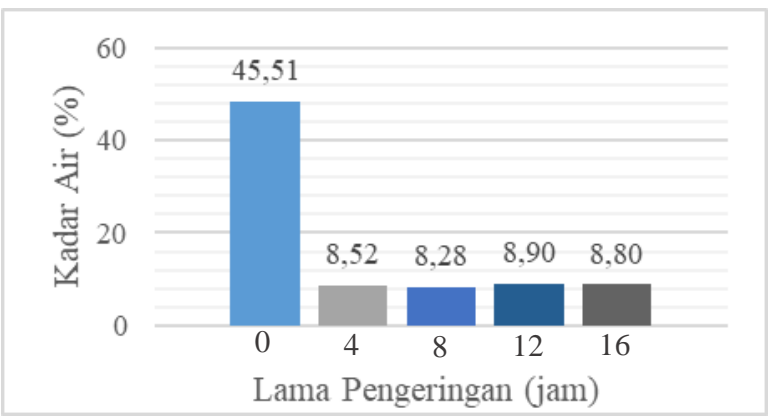

Gambar 2. Hubungan Lama Pengeringan terhadap Kadar Air Ubi Jalar Ungu

Hubungan antara penambahan asam askorbat dan lama pengeringan terhadap kadar air pati ubi jalar ungu pada semua konsentrasi penambahan asam askorbat menunjukkan terjadinya penurunan kadar air secara drastis dari lama pengeringan 0 jam menuju lama pengeringan 4 jam dan cenderung stabil pada lama pengeringan 8 jam, 12 jam, dan 16 jam. (Ramadani \& Yahya, 2018), memaparkan bahwa pada pengeringan 0 sampai 5 jam, kadar air akan menurun secara cepat dikarenakan suhu yang semakin tinggi dan kecepatan aliran udara pengering semakin cepat akan mengakibatkan proses pengeringan berlangsung lebih cepat.

\section{2 Kandungan Antosianin}

Hasil pengujian penambahan asam askorbat terhadap kandungan antosianin diperoleh rata-rata berkisar antara 4,34$6,01 \mathrm{mg} / \mathrm{kg}$. Kandungan antosianin tidak stabil terhadap konsentrasi penambahan asam askorbat. Hasil analisis menunjukkan bahwa penambahan asam askorbat sebanyak $0,5 \%-1,5 \%$ tidak memberikan perbedaan yang signifikan terhadap kandungan antosianin yang terdapat pada pati ubi jalar ungu. Kehilangan antosianin yang tinggi diduga terjadi pada saat ekstraksi pati yang menggunakan air sehingga sebagian besar antosianin larut dalam air. Menurut (Sukasih \& Setyadjit, 2016), stabilitas dan degradasi antosianin dapat dipengaruhi oleh berbagai faktor misalnya cahaya, $\mathrm{pH}$, suhu, sulfit, asam askorbat, dan lain-lain. Selain itu, menurut (Andarwulan \& Faradilla, 2012), asam askorbat, gula, asam amino, dan fenolik dapat mempercepat degradasi antosianin karena senyawa tersebut dapat berkondensasi dengan antosianin menghasilkan phlofaben yang berwarna coklat. Namun, (F.J. Francis, 1994; Hambali, Suryani, \& Widianingsih, 2004) bahwa asam askorbat terkadang dapat melindungi antosianin tetapi ketika antosianin menyerap oksigen, asam askorbat akan menghalangi terjadinya oksidasi. Hal ini sesuai bahwa asam askorbat dapat mempercepat degradasi antosianin, namun mekanismenya masih kontroversi.

Kandungan antosianin pada lama pengeringan 4 hingga 12 jam cenderung meningkat dan pada lama pengeringan 16 jam kandungan antosianin pada pati ubi jalar ungu menurun namun, perubahan perubahan kandungan antosianin yang diperoleh tidak signifikan. Antosianin merupakan senyawa yang sangat tidak stabil terhadap suhu dan asam askorbat. 
Suhu pengeringan yang semakin lama dapat menurunkan jumlah antosianin dalam bahan pangan. Ketidakstabilan antosianin terhadap suhu pengeringan dijelaskan oleh (Fajarwati, Parnanto, \& Manuhara, 2017) bahwa antosianin selama proses pengeringan dapat mengalami perubahan struktur menjadi khalkone yang sifatnya labil dan jika proses pemanasan diteruskan dengan adanya oksigen maka antosianin akan membentuk produk berwarna coklat. Pernyataan tersebut juga didukung oleh (Hermawan, Hayati, Budi, \& Barizi, 2010), yang menyatakan bahwa suhu tinggi menyebabkan hilangnya glikosil pada antosianin dengan hidrolisis ikatan glikosidik, aglikon yang dihasilkan kurang stabil sehingga menyebabkan hilangnya warna pada antosianin.

Kandungan antosianin yang dihasilkan cenderung fluktuatif diduga karena pengaruh dari penambahan asam askorbat dan pengeringan yang menggunakan suhu $60^{\circ} \mathrm{C}$. Rata-rata antosianin tertinggi yaitu pada pati ubi jalar ungu dengan penambahan asam askorbat $0,5 \%$ tanpa pengeringan sedangkan rata-rata antosianin terendah pada pati ubi jalar ungu penambahan asam askorbat $1,5 \%$ dengan lama pengeringan $12 \mathrm{jam}$. Asam askorbat dan suhu merupakan salah satu faktor yang dapat mempengaruhi stabilitas dan degradasi antosianin pada suatu bahan pangan. Asam askorbat dapat mempercepat degradasi antosianin dan menyebabkan perubahan warna menjadi coklat karena adanya0,kondensasi antara asam askorbat dan antosianin. Sedangkan pengeringan dengan penggunaan suhu tinggi juga dapat mengurangi antosianin yang menyebabkan rusaknya antosianin dalam bahan pangan. Sesuai dengan yang dipaparkan oleh (Sukasih \& Setyadjit, 2016) bahwa stabilitas dan degradasi antosianin dipengaruhi oleh berbagai faktor misalnya cahaya, $\mathrm{pH}$, suhu, sulfit, asam askorbat, dan lain-lain.

\subsection{Aktivitas Antioksidan ( $\mathrm{IC}_{\mathbf{5 0}}$ )}

Hasil pengujian penambahan asam askorbat terhadap aktivitas antioksidan ubi jalar ungu berkisar antara 1064,43-5017,77 ppm. Semakin tinggi konsentrasi penambahan asam askorbat maka semakin rendah pula rata-rata nilai $\mathrm{IC}_{50}$ yang diperoleh. Rendahnya nilai $\mathrm{IC}_{50}$ menunjukkan bahwa semakin tinggi aktivitas antioksidan pati ubi jalar ungu seiring dengan meningkatnya penambahan asam askorbat.

Hasil analisis menunjukkan bahwa nilai $\mathrm{IC}_{50}$ pati ubi jalar ungu penambahan asam askorbat $0 \%$ atau tanpa penambahan asam askorbat memiliki nilai tertinggi yang berarti aktivitas antioksidannya paling rendah. Sedangkan nilai $\mathrm{IC}_{50}$ pati ubi jalar ungu penambahan asam askorbat dengan berbagai konsentrasi lebih rendah yang berarti memiliki aktivitas antioksidan yang lebih tinggi daripada pati ubi jalar ungu penambahan asam askorbat $0 \%$. Sesuai yang dipaparkan oleh Lung dan Destiani (2017) bahwa asam askorbat atau vitamin $\mathrm{C}$ tergolong senyawa antioksidan yang kuat karena mempunyai rata-rata nilai $\mathrm{IC}_{50}$ yang relatif kecil.

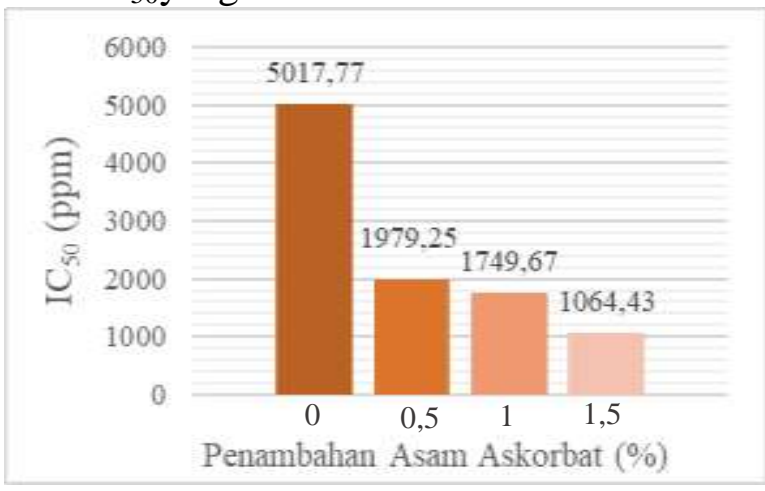

Gambar 3. Hubungan Penambahan Asam Askorbat terhadap Aktivitas Antioksidan Pati Ubi Jalar Ungu

Asam askorbat atau vitamin $\mathrm{C}$ memiliki nilai $\mathrm{IC}_{50}$ yang lebih rendah dibandingkan dengan vitamin $\mathrm{A}$ dan vitamin E. Hal ini disebabkan karena 
vitamin $\mathrm{C}$ merupakan senyawa yang lebih polar dibandingkan dengan vitamin $\mathrm{E}$ dan vitamin A. Vitamin C memiliki empat gugus hidroksil sedangkan vitamin $\mathrm{E}$ mempunyai satu gugus hidroksil dan vitamin A tidak memiliki gugus hidroksil, sehingga aktivitas antioksidan vitamin $\mathrm{C}$ lebih kuat dibandingkan dengan vitamin $\mathrm{E}$ dan vitamin A (Lung \& Destiani, 2017).

Hasil pengujian lama pengeringan terhadap aktivitas antioksidan pati ubi jalar ungu berkisar antara 1681,67-3534,01 ppm. Hasil analisis menunjukkan bahwa semakin lama pengeringan maka nilai $\mathrm{IC}_{50}$ juga semakin meningkat yang berarti semakin rendahnya aktivitas antioksidan pada pati ubi jalar ungu.

Lama pengeringan menyebabkan semakin rendahnya aktivitas antioksidan pati ubi jalar ungu. Hal ini diduga karena senyawa-senyawa yang bersifat sebagai antioksidan pada pati ubi jalar ungu tidak stabil terhadap pemanasan sehingga semakin lama pengeringan yang dilakukan maka semakin rendah pula aktivitas antioksidannya. Walaupun asam askorbat tergolong dalam antioksidan yang kuat namun, asam askorbat tidak stabil pada pemanasan yang berlebihan begitu pula dengan kandungan antosianin dalam pati ubi jalar ungu. (Syafrida, Darmanti, \& Izzati, 2018) menyatakan bahwa pengeringan dengan menggunakan temperatur yang tinggi dapat menurunkan aktivitas antioksidan.

Rata-rata nilai $\mathrm{IC}_{50}$ pati ubi jalar ungu dengan penambahan asam askorbat lebih rendah daripada rata-rata nilai $\mathrm{IC}_{50}$ pati ubi jalar ungu tanpa penambahan asam askorbat. Nilai $\mathrm{IC}_{50}$ pati ubi jalar ungu penambahan asam askorbat berkisar antara 249,25-3452,10 ppm sedangkan nilai $\mathrm{IC}_{50}$ pati ubi jalar ungu tanpa penambahan asam askorbat berkisar antara 3235,86$8199,36 \mathrm{ppm}$. Nilai $\mathrm{IC}_{50}$ yang cukup tinggi pada pati ubi jalar ungu dengan penambahan asam askorbat menandakan bahwa aktivitas antioksidannya masih sangat lemah. Namun, aktivitas antioksidan pati ubi jalar ungu penambahan asam askorbat lebih tinggi daripada aktivitas antioksidan pati ubi jalar ungu perlakuan blanching, dan masih jauh lebih rendah daripada aktivitas antioksidan vitamin $\mathrm{C}$ yang mempunyai nilai $\mathrm{IC}_{50} 21,09$ ppm (Hendarto \& Siregar, 2010).

\section{KESIMPULAN}

Pengaruh penggunaan asam askorbat dalam ekstraksi pati ubi jalar ungu terbukti menurunkan kandungan antosianin, namun meningkatkan aktivitas antioksidan pati ubi jalar ungu tersebut. Pada kondisi proses pengeringan selama 4 jam dengan konsentrasi penambahan asam askorbat antara $0,5 \%-1,5 \%$.

\section{DAFTAR PUSTAKA}

Abbasi, N. A., Akhtar, A., Hussain, A., \& Ali, I. (2013). Effect of anti-browning agents on quality changes of loquat Eriobotrya japonica (Thunb.) fruit after harvest. Pak J Bot, 45, 13911396.

Afandy, M. A., Nuryanti, S., \& Diah, A. W. M. (2017). Ekstraksi Ubi Jalar Ungu (Ipomoea batatas L.) Menggunakan Variasi Pelarut Serta Pemanfaatannya Sebagai Indikator Asam-Basa. Jurnal Akademika Kimia, 6(2), 79-85.

Andarwulan, N., \& Faradilla, R. H. F. (2012). Pewarna alami untuk pangan. Bogor : Seafast Cente

Arifiansyah, M. (2015). Karakteristik kimia (kadar air dan protein) dan nilai kesukaan keju segar dengan penggunaan koagulan jus. Students $E$ Journal, 4(1).

Arifuddin, W. (2018). Aktivitas Antioksidan Senyawa Antosianin dari Ekstrak Etanol Ubi Jalar Ungu (Ipomoea batatas L). Celebes Biodiversitas, 1(2), 26-29. 
F.J. Francis. (1994). Colorimetric properties of foods, Engineering Properties of Foods ((3rd ed)). https://doi.org/DOI:10.1201/9781420 028805.ch16

Fajarwati, N. H., Parnanto, N. H. R., \& Manuhara, G. J. (2017). Pengaruh konsentrasi asam sitrat dan suhu pengeringan terhadap karakteristik fisik, kimia dan sensoris manisan kering labu siam (sechium edule sw.) Dengan pemanfaatan pewarna alami dari ekstrak rosela ungu (Hibiscus sabdariffa L.). Jurnal Teknologi Hasil Pertanian, 10(1).

Firgianti, G., \& Sunyoto, M. (2018). Karakterisasi Fisik Dan Kimia Ubi Jalar Ungu (Ipomoea Batatas L) Varietas Biang Untuk Mendukung Penyediaan Bahan Baku Tepung Ubi Jalar Ungu. Prosiding Seminar Nasional Fakultas Pertanian UNS, 2(1), F-104.

Hambali, Suryani, A., \& Widianingsih, N. (2004). Membuat Aneka Olahan Mangga. Jakarta: Penebar Swadaya.

Helmalia, A. W., Putrid, \& Dirpan, A. (2019). Potensi Rempah-rempah Tradisional Sebagai Sumber Antioksidan Alami untuk Bahan Baku Pangan Fungsional. Canrea Journal: Food Techology, Nutritons, and Culinary Journal, 2(1), 26-31. https://doi.org/10.20956/canrea.v2i1.1 13

Hendarto, L., \& Siregar, T. M. (2010). Pemanfaatan ubi jalar ungu (ipomoea batatas 1. Poir) Sebagai Pengganti Sebagian Tepung Terigu dan Sumber Antioksidan pada Roti Tawar [Purple Sweet Potato (Ipomoea batatas L. Poir) as a Partial Subtitute of Wheat flour and Source of Antioxidant on Pla. Jurnal Teknologi Dan Industri Pangan, 21(1), 25.

Hermawan, R., Hayati, E. K., Budi, U. S., \& Barizi, A. (2010). Effect of temperature, $\mathrm{pH}$ on total concentration and color stability of anthocyanins compound extract roselle calyx (Hibiscus sabdariffa L). Alchemy, 2(1), 104-157.

Javdani, Z., Ghasemnezhad, M., \& Zare, S. (2013). A comparison of heat treatment and ascorbic acid on controlling enzymatic browning of fresh-cuts apple fruit. International Journal of Agriculture and Crop Sciences, 5(3), 186.

Kristijarti, A. P., \& Arlene, A. (2012). Isolasi zat warna ungu pada ipomoea batatas poir dengan pelarut air. Research Report-Engineering Science, 1 .

Lung, J. K. S., \& Destiani, D. P. (2017). Uji Aktivitas Antioksidan Vitamin A, $\mathrm{C}, \mathrm{E}$ dengan Metode DPPH. Farmaka, 15(1), 53-62.

Marshall, M. R., Kim, J., \& Wei, C. I. (2005). Enzymatic browning in fruits, vegetables and seafoods, 2000.

FAO.[(accessed on 9 July 2006)]. Available Online: Http://www. Fao. org/ag/ags/agsi/ENZYMEFINAL/Enzy matic\% 20Browning. Html.

Özoğlu, H., \& Bayındırlı, A. (2002). Inhibition of enzymic browning in cloudy apple juice with selected antibrowning agents. Food Control, 13(4-5), 213-221.

Ramadani, R. W., \& Yahya, M. (2018). Perubahan Kadar Air dan Kadar Pati Ubi Kayu (Manihot Utilissima) Selama Pengeringan Menggunakan Room Dryer. Jurnal Pendidikan Teknologi Pertanian, 3, 102-111.

Suda, I., Oki, T., Masuda, M., Kobayashi, M., Nishiba, Y., \& Furuta, S. (2003). Physiological functionality of purplefleshed sweet potatoes containing anthocyanins and their utilization in foods. Japan Agricultural Research Quarterly: JARQ, 37(3), 167-173.

Sukasih, E., \& Setyadjit, S. (2016). Pengaruh Perendaman Asam Askorbat dan Natrium Bisulfit pada 
Dua Varietas Bawang Merah (Allium ascalonicum L.) terhadap Sifat Fisikokimia dan Organoleptik

Tepungnya. Agritech, 36(3), 270-278.

Suprapto. (2004). Pengaruh Lama

Blancing Terhadap Kualitas Stik ubi Jalar Ipoema batatas L .) dari Tiga Varietas. Prosiding.

Syafrida, M., Darmanti, S., \& Izzati, M. (2018). Pengaruh Suhu Pengeringan Terhadap Kadar Air, Kadar Flavonoid dan Aktivitas Antioksidan Daun dan Umbi Rumput Teki (Cyperus rotundus L.). Bioma: Berkala Ilmiah Biologi, 20(1), 44-50.

Widhaswari, V. A., \& Putri, W. D. R. (2014). Pengaruh Modifikasi Kimia Dengan Sttp Terhadap Karakteristik Tepung Ubi Jalar Ungu. Jurnal Pangan Dan Agroindustri, 2(3), 121128.

Zhang, L., Zhao, L., Bian, X., Guo, K., Zhou, L., \& Wei, C. (2018).

Characterization and comparative study of starches from seven purple sweet potatoes. Food Hydrocolloids, 80, 168-176. 